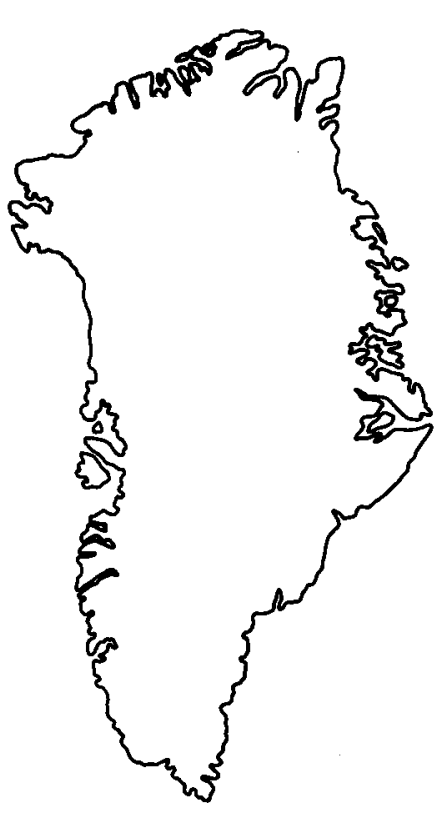

\title{
A second fossil occurrence from the Precambrian Shield of southern West Greenland
}

\author{
John S. Peel and Karsten Secher
}

\begin{abstract}
A recrystallised, calcareous, quartz sandstone, occurring as loose
blocks in the northern part of the Sarfartôq carbonatite complex,
contains possible annelid tubes and provides only the second
record of Phanerozoic rocks from the Precambrian Shield area
A recrystallised, calcareous, quartz sandstone, occurring as loose
blocks in the northern part of the Sarfartôq carbonatite complex,
contains possible annelid tubes and provides only the second
record of Phanerozoic rocks from the Precambrian Shield area

A recrystallised, calcareous, quartz sandstone, occurring as loose
blocks in the northern part of the Sarfartôq carbonatite complex,
contains possible annelid tubes and provides only the second
record of Phanerozoic rocks from the Precambrian Shield area

A recrystallised, calcareous, quartz sandstone, occurring as loose
blocks in the northern part of the Sarfartôq carbonatite complex,
contains possible annelid tubes and provides only the second
record of Phanerozoic rocks from the Precambrian Shield area of southern West Greenland.
\end{abstract}

J.S.P. \& K.S. Grønlands Geologiske Undersøgelse, Øster Vold-

gade 10, DK-1350 København K, Danmark.

During fieldwork in 1977 in connection with the radiometric survey of the Søndre Strømfjord area (Secher, 1976), loose blocks of a quartz-carbonate rock containing possible fossil remains (fig. 1A-E) were discovered in the northern part of the Sarfartôq carbonatite complex (Secher \& Larsen, 1978). About $20 \mathrm{~kg}$ of fossiliferous samples (GGU 225215) were collected within an area of $40 \mathrm{~m}-50 \mathrm{~m}$, located on a slightly inclined north facing slope.

Blocks of fossiliferous limestone of Middle to Late Ordovician age have previously been described from near Sukkertoppen, about $130 \mathrm{~km}$ to the south of the present locality, by Poulsen (1966, 1967) and Stouge \& Peel (this report). The material described here thus represents the second find of fossiliferous rocks within the Precambrian terrain of southern West Greenland. Unfortunately, strong recrystallisation and the simple nature of the probable annelid tubes only permits the assignment of a general Cambrian to Recent age, at this time. However, the new material is of considerable interest in suggesting the possible widespread occurrence of a former cover of sedimentary Phanerozoic rocks on the Precambrian Shield of southern West Greenland.

\section{Petrography}

Macroscopically, the fossiliferous material is a strongly weathered, reddish brown quartzcarbonate rock. Fresher surfaces show patches of glassy quartz set in a pale pink-brown groundmass. Druses of colourless to white quartz containing euhedral crystals up to $5 \mathrm{~mm}$ are common. Microscopic examination revealed that the rock is made up of euhedral to subhedral quartz grains (size up to $2 \mathrm{~mm}$ ) set in an equiangular groundmass. Carbonate (ferruginous calcite and dolomite) occurs as subhedral to euhedral grains (up to $1 \mathrm{~mm}$ ), as dust-like inclusions within the quartz, in small patches, and possibly in the zone of radiating crystals around the fossil tubes. 

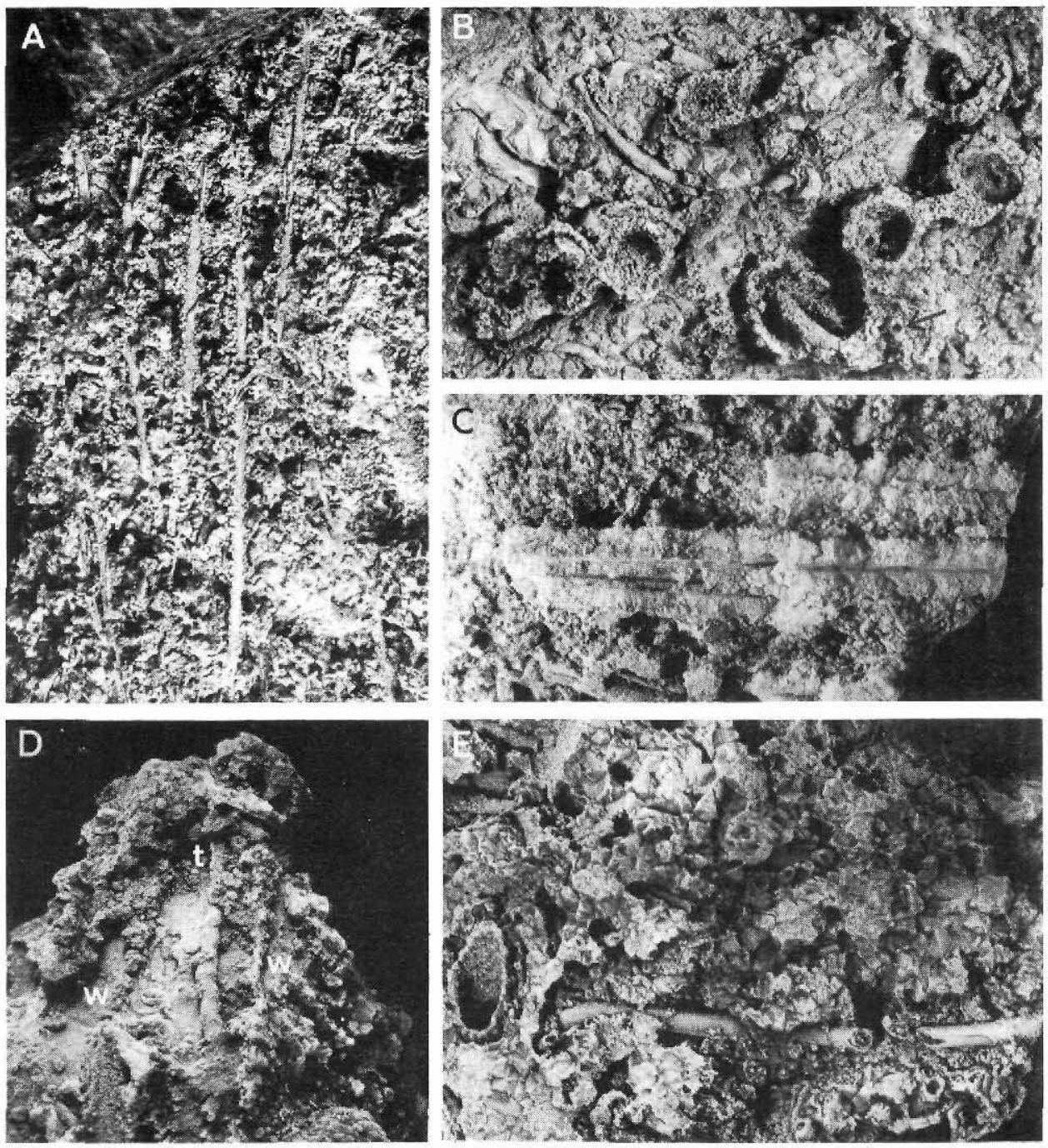

Fig. 1. Fossil tubes and recrystallisation phenomena, GGU 225215. A, well oriented tubes, each surrounded by a thin zone of subsequent crystal growth, MGUH 14131, × 1.67. B, recrystallised halos around tubular fossils (arrow) weathering out in cross section to form colonial pseudofossils, MGUH 14132, $\times 2$. $\mathrm{C}$, longitudinal weathered section of tubular fossils surrounded by radiating recrystallised barite and quartz, MGUH 14133, $\times 1.5$. D, weathered pseudofossil. as B but in longitudinal section. A central tube (t), made irregular by subsequent crystal growth, forms the axis of a crude rod-like zone of crystal growth in which the abaxial wall $(w)$ is positive weathering, MGUH 14132, $\times 2$. E, bent tubular fossil surrounded by a thin zone of crystal growth. The open tube to the left is the etched hollow outer wall of a recrystallisation halo, as in B. MGUH 14132, $\times 1.2$. All specimens are whitened with ammonium cloride sublimate. 
The third principal mineral is barite which occurs either as scattered tabular euhedral crystals up to $0.5 \mathrm{~mm}$ or together with carbonate and quartz in the radiating intergrowths around the tubes (figs 2, 3).

The rock appears to be a totally recrystallised calcareous, quartz sandstone.

\section{Fossil material}

The sample contains a number of tubular fossils of uncertain affinity. The tubes have formed the loci for subsequent crystal growth (figs 2,3), discussed in the next section.

The most common remains are thin $(c .1 \mathrm{~mm})$ straight, or gently curved tubes, with a circular cross-section, which may reach $35 \mathrm{~mm}$ in length (fig. 1A). Details of surface sculpture are obscured by the generally poor preservation but there is some suggestion of concentric ornamentation on a few tubes. More rarely, a coarse annulation is apparent. Broken surfaces sometimes show a crude lamellar structure, in other cases a radiating fibrous structure, but both these reflect subsequent recrystallisation around the original thin shell. The thickness of the tube walls when
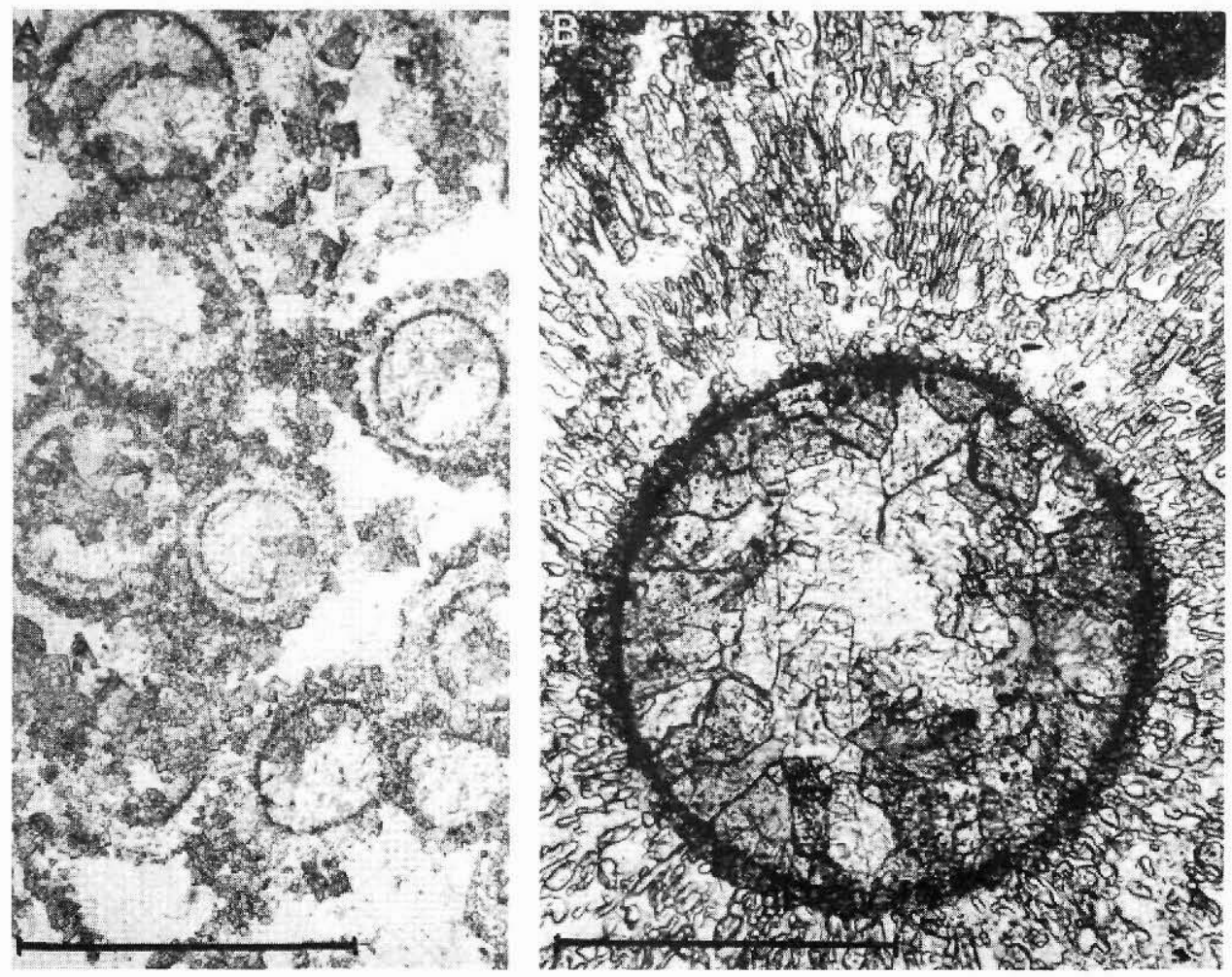

Fig. 2. Transverse sections of fossil tubes surrounded by halos of recrystallised quartz with barite inclusions, MGUH 14134 from GGU 225215, plane polarised light. A, length of bar $=1 \mathrm{~mm}$. B, Transverse section of a single tube. The thin walled tube, composed of fine grained dark carbonate, is surrounded by large quartz crystals with inclusions of radiating crystals of barite. The tube is largely filled with dolomite and barite, length of bar $=250 \mu \mathrm{m}$. 

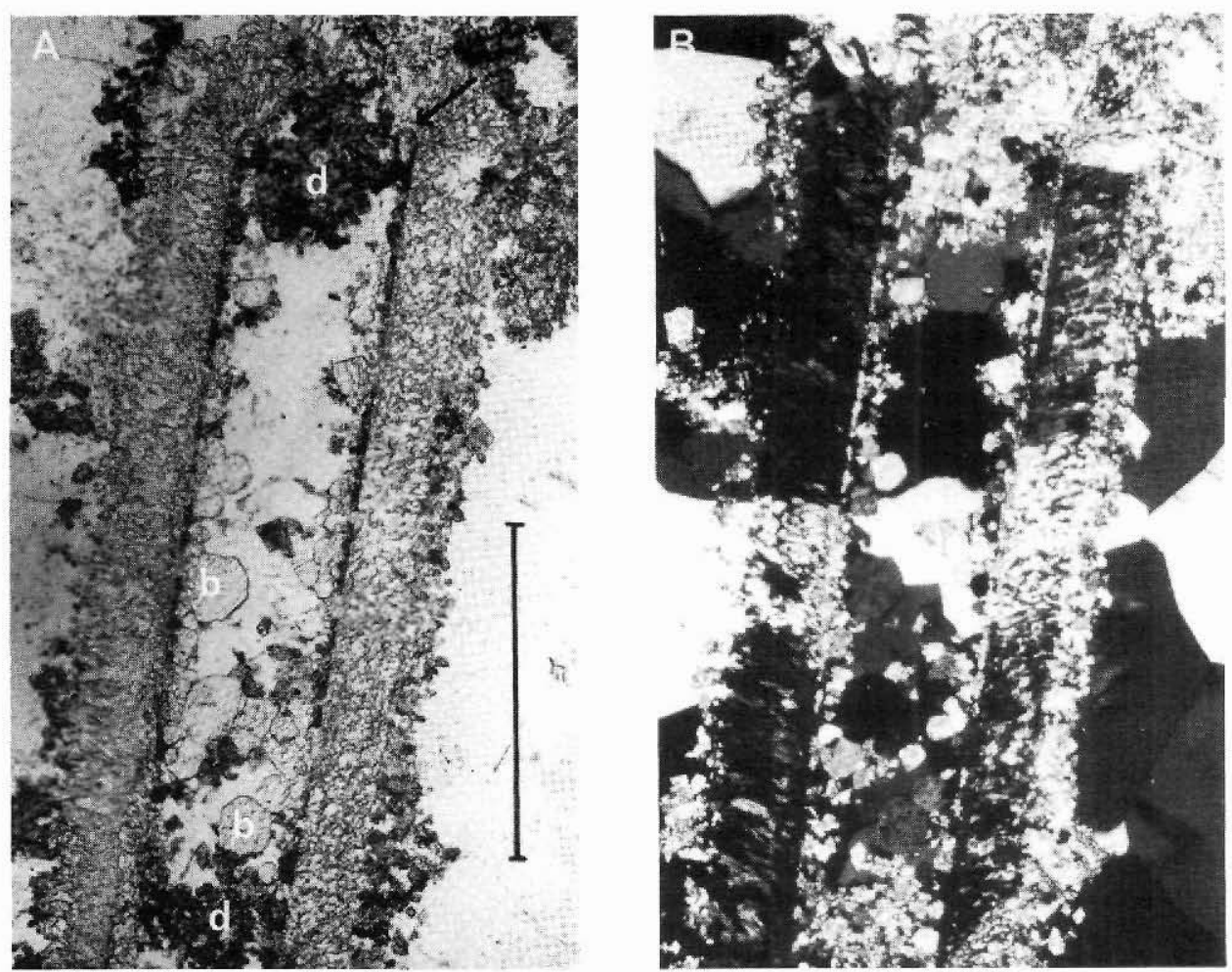

Fig. 3. Longitudinal section of a single tube with recurved brim (arrow), MGUH 14135 from GGU 225215 , length of bar $=1 \mathrm{~mm}$. Large quartz crystals are optically continuous through the tube. Crystals of barite (b) and fine grained dolomite (d) occur within the tube which is surrounded by radiating crystals of barite in quartz. A, plane polarised light. B, crossed nicols.

examined in the specimen is also variable $(0.1 \mathrm{~mm}$ and thicker) but this is again probably the result of variable recrystallisation. In thin sections, the thickness is clearly considerably less. In MGUH 14135, a longitudinal section (fig. 3), a narrow recurved brim is clearly evident.

The tubes, and much of their filling, seem to be calcite, readily removed by dilute acetic acid, but a zone seemingly rich in barite and perhaps dolomite of variable thickness (see next section) and insoluble in the acid generally surrounds the tube. After etching in acid and removal of the calcite, the resultant 'outer tubes' are rough and coarsely delimited on the external surface, perhaps due to the subsequent crystal growth around the fossil tubes. Internally, forming an external mould to the digested calcite tube, the residual barite rich 'outer tube' is smooth and clearly delimited.

The tubes are frequently well oriented (fig. 1A), although in at least one sample two principal directions of orientation lie perpendicular to each other.

A second group of tubes, less common than the first, includes irregularly bent forms with a slightly greater width than most of the straight or gently curved tubes (fig. 1E). Two examples showed well preserved, fine, concentric growth lines on the outer surface of the somewhat irregularly flattened tube. 
The nature of the original tubes is problematic, but tentative assignment to the Annelida is made. The Cretaceous serpulid Longitubus has a straight, originally calcareous shell with fine concentric growth lines, but tends to be two or three times thicker than most of the straight tubes in GGU 225215, although the finely ornamented, bent tubes more closely approach Longitubus in thickness. However, generally similar serpulids are known from the Lower Palaeozoic to Recent (Howell, 1962), while morphologically similar tubes of uncertain affinity extend back to the earliest Cambrian. An age assignment other than Cambrian to Recent is not currently possible.

A portion of GGU 225215 was crushed $(0.5 \mathrm{~mm}$ to $1 \mathrm{~cm})$, treated with dilute acetic acid and the resultant fine residue separated in tetrabromoethane. No organic traces were observed in the residue.

\section{Recrystallisation phenomena}

The most conspicuous 'remains' in GGU 225215 appear to result from post depositional recrystallisation and crystal growth around the tubes described in the previous section - the originally hollow tubes probably provided a convenient medium for mineral migration and a locus for crystal growth.

On weathered surfaces the crystal growths often resemble colonial organisms (fig. 1B). When the radiating crystal structure is more clearly visible, in longitudinal section, straight or gently curved crystal growths may even superficially resemble longitudinally split belemnite guards (fig. 1C) or even bryozoans. However, closer examination demonstrates that although the central tube is undoubtedly organic, the surrounding material is of subsequent, inorganic origin (figs 2 , 3).

The most conspicuous crystal growth phenomena within the available material are characterised by a well developed radiating fibrous structure around a narrow, distinct, axial tube. Straight or gently curved fragments up to $40 \mathrm{~mm}$ long and $5 \mathrm{~mm}$ thick have been observed. Radiating crystals, which in thin section prove to be rich in finely divided barite needles set in quartz, often curve away from the axial tube so as to be generally perpendicular to the long axis, abaxially. The width of the radiating crystal zone is variable - in some cases the entire rod may be less than $1 \mathrm{~mm}$ wide, with the central fossil tube occupying about one third of this width. All gradations occur up to the maximum observed thickness of $5 \mathrm{~mm}$ in which the axial canal is about $0.5 \mathrm{~mm}$. The rods are often only crudely parallel sided and in some cases exhibit an irregular pinch and swell structure ( $t$ in fig. 1D).

A slightly different form is shown by a second loosely defined group of structures. These perhaps represent an intermediary, or imperfect stage in the sequence of formation of the well developed radiating crystal structure. The central, fossil, tube is again distinct (fig. 1B, D) but is not surrounded by a compact zone of radiating crystals. Instead, a crude concentric distribution of recrystallized material is present, with a strongly developed outermost band. In weathered specimens (fig. 1B, D) this outermost band tends to form a prominent outer wall. In thin section the concentric bands are seen to have a fine crystal texture, radiating from the central tube. Areas of 'normal' sediment occur within the prominent outer wall. 


\section{References}

Howell, B.F. 1962: Worms. In Moore, R.C. (edit.) Treatise on Invertebrate Paleontology, W, Miscellanea, 144-177. Kansas U. Press.

Poulsen, V. 1966: An occurrence of Lower Palaeozoic rocks within the Precambrian terrain near Sukkertoppen. Rapp. Grenlands geol. Unders. 11, 26 only.

Poulsen, V. 1967: Grønlands geologi: Palaeozoikum. Københavns universitets fond til tilvejebringelse af læremidler, $99 \mathrm{pp}$.

Secher, K. 1976: Airborne radiometric survey between $66^{\circ}$ and $69^{\circ} \mathrm{N}$, southern and central West Greenland. Rapp. Gronlands geol. Unders. 80, 65-67.

Secher, K. \& Larsen, L.M. 1978: A new Phanerozoic carbonatite complex in southern West Greenland. Rapp. Grønlands geol. Unders. 90, 46-50. 